\title{
EVANGELIE EN WET IN DE EXEGESE VAN HET OUDE TESTAMENT ${ }^{1}$ )
}

De onderlinge verhouding van Evangelie en wet is het probleem bij uitnemendheid der exegese. $\mathrm{Ze}$ vormt het middelpunt, dat allen uitleg beheerscht. Vroeger of later wordt alle exegese naar deze norm geoordeeld. Van het antwoord op de vraag, hoe wij de onderlinge verhouding van Evangelie en wet zien, zijn naast andere dingen onze opvatting van den Kanon, ons verstaan van de $H$. Schrift en onze vertaling van iedere bladzijde van den Bijbel afhankelijk. Anderzijds moet ook erkend worden, dat onze opvatting omtrent de verhouding van Evangelie en wet bepaald wordt door ons buigen voor den Kanon, ons Reformatorisch verstaan van de Schrift, en ons geloovig vertalen der teksten. Hier is een circulus, die door ieder, die zich er niet in beweegt, ongetwijfeld met het epitheton ",vitiosus" bestempeld zal worden. Zoo moet het ook zijn. Er leidt geen menschelijke, in étappes uiteen te leggen, weg naar het geloof. Theologie is geen logica, maar grammatica, ${ }^{2}$ ) en elke grammatica veronderstelt bij het begin reeds het geheel.

$\left.{ }^{2}\right)$ Oorgeneem uit: Onder eigen Vaandel 13, 2 (1938). Uitg. Veenman en Zonen, Wageningen.

$\left.{ }^{2}\right)$ Luther: Theologie ist Grammatik. 
In nr. 32 van de serie Theologische Existenz Heute heeft Bartb de onderlinge verhouding van Evangelie en wet uiteengezet. $\left.{ }^{3}\right)$ Misschien was het echter beter, zoo wij het woord "verhouding" hier vermeden; Evangelie en wet zijn immers zoozeer één in God, dat men haast niet meer van een "verhouding" spreken kan. Zoodra wij dat woord gebruiken, trekken wij die beide een eind weegs uit elkander, en dat is al weer een spreken vanuit het ongeloof. Wat wij wet noemen, is als Evangelie gegeven, en wat ons als Evangelie gegeven is, wordt wet, zoodra wij vergeten dat het ons gegeven is. Barth schrijft: „Wanneer ook de wet Gods woord is, wanneer het echter genade is, dat Gods woord klinkt en hoorbaar wordt, en wanneer genade niets anders heeten kan dan Jezus Christus, dan is het niet slechts onzeker en gevaarlijk, maar bepaald verkeerd, Gods wet uit eenig ding, uit eenig gebeuren te willen aflezen, dat te onderscheiden valt van het gebeuren, waarin ons de wil Gods, den sluier van onze theoriëen en uitleggingen verscheurend, zoowel naar inhoud als vorm als genade zichtbaar wordt (p. 9). Dat is hetzelfde, als den Joden in Joh. 6 vs. 28,29 geantwoord wordt op hun vraag: Wat zullen wij doen, opdat wij de werken Gods mogen werken? Christus antwoordt daar immers op: Dit is het werk Gods, dat gij gelooft in Hem, dien Hij gezonden heeft.

Hieruit kunnen wij in de eerste plaats opmaken, dat het onmogelijk is, een Christelijke ethiek op te bouwen, door van de dramatiek van zonde en genade terug te keeren naar de scheppingsordeningen. Het is een hoogst opmerkelijke zaak, dat vrijwel iedere Christelijke ethiek, die verder wil gaan dan het ééne gebod, te gelooven in Jezus Christus, zijn basis zoekt in de scheppingsordinantiën. Natuurlijk kan men niet loochenen, dat er op de een of andere wijze scheppingsordinantiën kunnen zijn. Maar wanneer men van de leer van dit verbond iets meer wil maken dan de erkenning van de oikonomia tou theou, wanneer men poogt de scheppingsordinantiën hier voor ons kenbaar te maken, ze met behulp der empirie tracht aan te wijzen, dan valt men in een dubbele fout; in de eerste plaats verraadt men, dat men nog niet verstaan heeft quanti ponderis sit peccatum; men laat de scheppingsordinantiën rustig doorwerken, alsof de zonde de oikonomia tou theou althans voor ons oog niet radicaal verbroken had. Men draagt geen leed over deze wereld, en nog veel minder over het eigen hart. Het eenige bezwaar, dat deze wereld vertoont, zijn de anderen, die niet dezelfde levensbeschouwing hebben als wij. Maar als „ons Christelijk volksdeel" de overwinning bij de stembus heeft behaald, is de handhaving der scheppingsordinantiën in de handen van "onze" mannen veilig.

s) K. Barth: Evangelium und Gesetz, München 1935 . 
In de tweede plaats wordt hier genade tot een soort van bovennatuurlijke verlichting, waardoor de wedergeboren mensch een speciaal vermogen krijgt om in den chaos van deze wereld een goddelijken kosmos na te speuren. Dat is de gratia infusa der Roomsche kerk in het intellectueele overgebracht; tegelijkertijd speelt hier de piëtistische verheerlijking van den wedergeboren mensch een rol. Men zou haast kunnen vragen, waarom de bekeerde mensch nog sterven moet, en hoe Luther zijn "Sermon von den guten Werken" besluiten kan met de belijdenis, dat de lichamelijke dood om der zonden wil juist voor den geloovigen mensch nuttig en wenschelijk is, .,des helff uns Gott."

Daar komt nog een derde overweging bij. Wat uit de scheppingsordinantiën wordt afgeleid komt wonderwel overeen met de burgerlijke levenswijze van den democratisch gezinden middenstand, waaruit vrijwel al deze theologen stammen, en waar zij hun lezers en volgelingen vinden. Wanneer de andere klassen ook nog den tijd vonden, om zich met de scheppingsordinantiën bezig te houden, zouden wij naar alle waarschijnlijkheid systemen opgediend krijgen, die nauw verwant waren met de levenswijze b.v. van een werklooze of van een grootkapitalist. Zulke systemen zouden op ons ongetwijfeld een zeer onbehagelijken indruk maken, even onbehaaglijk als de middenstandsscheppingsordinantiën den werklooze of den grootkapitalist voorkomen.

Iedere politiek en economische opvatting kan met scheppings.ordeningen verdedigd en bestreden worden. Op zich zelf is dat niet zoo erg; naar onze meening mag men niet zeggen, dat Gods wil voor alle tijden het eene dan wel het andere staatkundige en sociale systeem eischt. Maar de ethiek, die haar steun zoekt in de scheppingsordinantiën, heeft de pretentie, daarin materieele geboden te vinden, en wil richtlijnen trekken voor de keuze tusschen de verschillende mogelijkheden op het gebied van staat en maatschappij, die zich op ieder willekeurig oogenblik der geschiedenis kunnen opdoen. Dat moet onkritisch heeten. Men meent iets uit de schepping af te lezen, en wil niet tegenover zich zelf erkennen, dat men in zijn keuze tusschen de oneindig vele mogelijkheden der scheppingsordinantiën subjektief bepaald is.

Daaruit volgt derhalve; dat wij voor onze kennis omtrent hetgeen wij ,wet" noemen, nièt naar de schepping toe moeten, maar aangewezen zijn op de Woordopenbaring. Terstond komt nu een tweede vraag op, namelijk deze, of wij werkelijk, zooals het citaat uit Barth scheen te zeggen, in het Woord nooit iets anders kunnen vinden dan de boodschap van Gods genade, anders gezegd het Evangelie van Jezus Christus. Niemand zal loochenen, dat wij den geheelen Bijbel door 
het getuigenis van Christus kunnen hooren'). Maar is ons in diezelfde boeken van Oude en Nieuwe Verbond ook nog niet iets anders gegeven, richtlijnen voor den opbouw van het aardsche leven? Is er niet een wet, die in zich zelf iets te zeggen heeft, hetzij ze aan het Evangelie voorafgaat, hetzij ze als taak ons opgedragen wordt, nadat het Evangelie ons geworden is? Kunnen wij niet op de een of andere wijze wet en Evangelie een eind weegs uit elkander houden, zoodat wij de hand leggen op iets, dat wij als wet kunnen gebruiken en toepassen, zonder terstond door het Evangelie bij deze bezigheid gestoord te worden?

De dialectische theologie beantwoordt deze vraag ontkennend, en dat naar onze meening terecht. $E_{r}$ is geen aparte wet, die als wet gelden kan, ook wanneer men ze losgewrongen heeft van de belofte. Het heeft echter zijn nut, aan te toonen, hoe deze stelling door de exegese gesteund wordt, en anderzijds, hoe deze stelling de exegese leiden kan; ook hier weer een cirkelgang!

In de eerste plaats willen wij vaststellen, dat het onmogelijk is, het O.T. te vereenzelvigen met de wet, en het N.T. met het Evangeliz. Het is onmogelijk vol te houden, dat het O.T. Evangelielooze wet is, als men let op het zeven keer $^{5}$ ) voorkomende: Barmhartig en genadig is de Heere, lankmoedig en groot van goedertierenheid-dat telkenmale de inleiding is tot een getuigenis van de vergeving der zonden. De inwendige dialectiek der zaak, het $z \mathrm{ij}$ in het voorbijgaan opgemerkt, komt in Jona 4 duidelijk aan het licht. Daar wordt immers juist Gods barmhartigheid voor Jona een ergernis en een oordeel: het Evangelie van de vergeving der zonden is den profeet tot een wet, die doodt, geworden.

Wanneer niettemin eenige malen in het N.T. het O.T. kortweg met het woord ",wet" aangeduid word $\left.t^{6}\right)$, hebben wij daarin een enkel formeele aanduiding te zien. Hier zou overigens de vraag gesteld kunnen worden, of de Septuaginta een gelukkige hand had, toen zij het Hebreeuwsche tora weergaf met het Grieksche nomos. Gelijk bekend is, is het woord tora verwant met jara'), welks Hif'il „onderwijzen" beteekent. Tora kan dus het beste met "onderwijzing" weergegeven worden. Niet met "leer", want "leer" kon verkeerd worde opgevat als een afgesloten en afgerond systeem van geopenbaarde waarheden, een systeem, welks openbaring een prijsgave aan de ver-

") Dit ",kunnen" duidt natuurlijk een theologische, geen psychologische moge2: 13 .

s) Ex. 34: 6; Neh. 9: 17; Ps. 86: 15; 103: 8; 145: 8; Jona 4: 2; Joël

$\left.{ }^{\circ}\right)$ B. v. Gal. 4: 21, waar het gaat over een geschiedenis uit het O.T.

) Een directe afhankelijkheid van Babylonisch têrtu is op grond van de vokalen onwaarschijnlijk te achten. 
starring beteekende. De substantiva met t-praefix zijn meer aanduiding van handelingen dan van resultaten of voorwerpen der handeling.) Vandaar de vertaling: onderwijzing. Iedere onderwijzing heeft als zoodanig een normatief karakter, en is zoodoende eenigermate verwant met datgene, wat wij wet noemen; maar iedere onderwijzing wordt gedragen door Eén, die zich nederbuigt om op te heffen, derhalve door de barmhartigheid. De onderwijzing is niet enkel eisch; zij doet ook iets, zij brengt iets tot stand, en is zoo eenigermate verwant met datgene, wat wij Evangelie noemen.

Wanneer de apostel Paulus dus het woord nomos gebruikt, zullen wij dat niet terugvertalen met tora. Men zou beter aan woorden als micwa e.d. kunnen denken, maar moet vóór alles zich er rekenschap van geven, dat feitelijk niet het O.T. of een deel daarvan bedoeld is, doch bepaalde functies van de openbaring, die ons in het O.T. ten deel geworden is, waarbij wij dan opmerken, dat ook de N.T.-ische openbaring dergelijke functies kan vervullen.

Kunnen wij de tegenstelling Evangelie-wet dus niet verdeelen over Nieuwe en Oude Testament, een andere vraag is het, of er in het Oude Testament geen stukken aan te wijzen zijn, die wij, zonder aan onze betrekking tot deze stukken te denken, in zichzelve reeds als "wet" zouden kunnen bestempelen. Zulk een isoleering van een stuk der Heilige Schrift moet echter als ongeoorloofd worden beschouwd. Het is zeker waar, dat wij bij het kerkelijk gebruik der Schrift, hetzij bij de openbare godsdienstoefening, hetzij bij persoonlijke Bijbellectuur, steeds slechts met een bepaald gedeelte te doen hebben, met een pericoop, maar evenzoo waar is het ook, dat het ",afbikken", begrenzen, het koptein, altijd slechts peri, rondom, gescheidt, en dus enkel een horizontale grens markeert. Naar boven en naar beneden, in de hoogte en in de diepte, bewaart ook het afgezonderde stuk zijn gemeenschap met het geheel, d.w.z. wij mogen nooit vergeten, dat ook zulk een afzonderlijk stuk deel van den kanon is, en slechts door zijn betrekking tot het geheel zin en beteekenis voor ons krijgen kan. Anders was er immers in het geheel geen aanleiding om zulk een brokstuk oude literatuur te lezen. Wie een deel der Heilige Schrift leest, leest dit altijd als de Heilige Schrift, d.w.z. als het getuigenis van Jezus Christus. Hij nadert het gedeelte met een zekere verwachting. Deze verwachting is het geloof, dat wij in iedere Schrift het Woord Gods, en dat is immers altijd Jezus Christus, hooren moeten en hooren kunnen. Natuurlijk is het denkbaar, dat de Schrift ook op een andere wijze gelezen wordt, b.v. op historisch-literaire wijze, doch wij hebben zulke gewoonte niet, noch de gemeenten Gods.

Zoo kunnen wij dus nimmer het stuk der Schrift isoleeren, zonder enz.

') Vgl. bv. tochèlet, verwachting, tokàchat, terechtwijzing, toda, lofzegging,

T.S. 2 
dit tot iets anders dan Heilige Schrift te maken. Hier moet ons verlangen naar abstracties halt houden. leder stuk staat in levende gemeenschap met het geheel der openbaring, en wordt door ons altijd in het geloof aan dit geheel gelezen. Het was echter wellicht niet overbodig, deze stelling ook practisch uit te werken in de exegese van enkele pericopen uit het O.T., en dat dan met bijzondere aandacht voor het probleem, aangeduid in de woorden Evangelie en wet.

Van Evangelie en wet kan eerst dan sprake zijn, als de zonde binnengedrogen is, d.w.z., als er een mensch is in dezelfde kommervolle omstandigheden als wij. Wenden wij ons derhalve tot de vervloekingen, door God gesproken onmiddellijk nadat door Hem de zonde aangewezen is. De arbeid van man en vrouw wordt onder den vloek geplaatst. Men wachte zich voor de gnostieke gedachte. als zou arbeid en baren in zich zelf iets vloekwaardigs zijn. Men wachte zich echter evenzeer-en. dat gevaar is actueerler!-voor het onbeschaamde optimisme van burgerlijke moralisten, die altijd weer over den zegen van den arbeid spreken, of voor de smakeloze praat van de beoefenaren der sexueele ethiek, die zich te!kens weer inspannen, om ons aan te praten, als zou het geslachtsleven iets heel gewoons, in het geheel niets geheimzinnigs zijn, men zou haast zeggen, iets heel gemoedelijks. Dat beteekent immers niets anders dan een poging om de dingen te bevrijden van den vloek, die van Gods wege op hen rust.

De hoogste verschijnselen in het menschenleven, arbeid en baring. die bij de heidenen altijd den mensch Gode gelijk maken, worden onder den vloek gebracht. Formeel bevestigt deze vloek hun hooge waarde; hij bewerkt echter hun vernedering. Doch daaraan vooraf gaat het woord van vijandschap tusschen de vrouw en de slang, het woord, dat de kerk het protevangelion genoemd heeft. De Messiaansche uitleg van.Gen. 3:15 is niet in het N.T. te vinden, doch behoort tot den schat der Kerk. Het moet daarom betreurd worden, dat men telkens tracht, dit woord van zijn karakter van protevangelion te berooven. Ongetwijfeld heeft $\mathrm{Th}$. C. Vriezen, om een voorbeeld te noemen, volkomen gelijk, als hij het ,zaad" van Eva als aanduiding van een collectivum opvat, niet als heenwijzing naar een speciaal individu'); maar afgezien van het feit, dat de tegenstelling individu en collectivum in het geheel niet past in het oud-Oostersch denkleven $\left.{ }^{2}\right)$, het dus ook geen uitgangspunt voor het stellen van exegetische problemen mag zijn, moet toch altijd bedacht worden, dat het eigenlijke Evangelie in dezen tekst niet gelegen is in de even-

9) Th. C. Vriezen, in zijn voortreffelijk Onderzoek naar de paradijsvoorstelling bij de oude Semietiesche volken. Wageningen, 1937, p. 184.

${ }^{10}$ ) Men zie bv. in 1 Kron. $7: 22$ dat Effraim als persoon rouw draagt over den dood van zijn nakomelingen uit het zevende geslacht; vgl. ook Jer. $31: 15$ en Mt. 2: 18. 
tueele daden van een nakomeling der vrouw, doch in de door God gestelde vijandschap. Dit is de belofte, die als belofte Gods in het menschenleven, zoolang ze "slechts" belofte blijft, werkende werkelijkheid is, namelijk dat er vijandschap is en blijft tusschen de zondaars en hun verleider. Er zal vijandschap zijn: ook als zondaar zal men den duivel haten, en dat niet omdat men nog niet geheel en al zondaar is, maar enkel krachtens de nieuwe daad van God. het stellen van de vijandschap. Deze is dus geen natuurlijke, van zelf sprekende zaak, maar berust op het woord Gods. $Z_{i j}$ is er nu, en stoort de volledige gemeenschap van den mensch met den duivel.

En wat is het eigenlijk duivelsche? Het is de macht, die Gods. wet misduidt, die uit de wet Gods, welke in zich zelf Evangelie is-gegeven, opdat de mensch niet zou sterven, maar het eeuwige leven hebbe-de mogelijkheid der overtreding afleidt; dus de macht, die het gebod aanwendt als een uitgangspunt tot een van God losgemaakte vrijheid. Alzoo is dan de wet heilig, en het gebod is heilig en recht vaardig en goed. Maar de zonde, oorzaak genomen hebbende door het gebod, heeft mij verleid, en door hetzelve gedood. ${ }^{11}$ )

Met deze misduiding van Gods wet, met deze zondemacht zal krachtens God genadebeschikking de mensch te strijden hebben. Hij zal geen vrede hebben met de zonde. Dat is genade, dat is het Evangelie reeds. Gods treedt hier immers tusschen den mensch en de zonde, al is het slechts met het woord vijandschap. Of moeten wij dit een wet noemen? Dit woord schijnt namelijk tot den mensch te zeggen: Gij moet strijden, immer opnieuw den kamp aanvaarden, na duizend nederlagen en vernederingen moet gij het gevecht opnieuw beginnen, en nimmer moogt gij rust vinden. Dat kan inderdaad een zeer strenge wet worden, waaronder de mensch uitroept: Wat is de mensch, dat Gij hem groot acht, en dat Gij uw hart op hem zet? En dat Gij hem bezoekt in elken morgenstond? Dat Gij hem e!k oogenblik beproeft? Hoe lang keert $\mathrm{Gij}$ u niet af van mij? en laat niet van mij af, totdat ik mijn speeksel inzwelge? Heb ik gezondigd, wat zal ik U doen, o Menschenhoeder? waarom hebt Gij mij U tot een tegenloop gesteld, dat $\mathrm{ik}$ mijzelven tot een last zij? En waarom vergeeft $\mathrm{Gij}$ niet mijne overtredingen, en doet mijne ongerechtigheid niet weg? Want nu zal ik in het stof liggen; en Gij zult mij vroeg zoeken, maar ik zal niet zijn.

Dat is inderdaad leven onder de wet; maar de wet is niet los van het Evangelie. Dit leven, gelijk het in al zijn vertwijfeling geteekend is, wordt niettemin gedragen door een belofte, die zich zelve juist in deze klachten en verwijten voor Gods aangezicht openbaart, en die onbekend is aan degenen, over wie Ps. 73 spreekt: hunne oogen puilen uit van vet; $z i j$ gaan de inbeeldingen des harten te boven...

1) Rom, $7: 12$ en 11 . 
zij zijn niet in de moeite gelijk andere menschen, en worden met andere menschen niet geplaagd.

Korten tijd later klinkt Eva's jubel na de geboorte van Kaīn: Ik heb een man verworven met den Heere. ${ }^{2}$ ) Wat heeft dat te beteekenen? Dat kan toch wel niets anders aanduiden, dan dat de vrouw meent, dat zij den slangendooder ter wereld heeft gebracht. Deze man, dien zij gebaard heeft—zij het dan ook "met den Heere", zij is het toch, die hem verworven heeft!-deze man zal de belofte, die $z \mathrm{ij}$ in het protevangelion meent gehoord te hebben, tot werklijkheid maken. Dat wil dus zeggen: zij grijpt aan de wet voorbij naar het Evangelie, zij streeft naar iets anders dan de van Gods wege ingestelde vijandschap, zif meent, dat met deze geboorte de tusschengeschoven tijd van strijd voorbij zal zijn: het nieuwe leven zal er een zijn zonder moeite en benauwenis.

Vandaar, dat de naam van den tweeden zoon Hébel luidt : ,ijdelheid", dat wat nergens toe dient. Waarom deze nieuwe geboorteweeën, als de Verlosser reeds geboren is? De menschheid neemt het Evangelie in eigen hand, grijpt naar de belofte, zonder zich onder de wet te stellen. Kaïn wil niet weten, dat hij onderworpen is aan Gods vrijmachtige beslissingen. Zoo wordt hij de broeder-moordenaar, en eerst als geoordeelde broedermoordenaar onder de dooding van Gods wet wegzinkende in vrees en beven, ontvangt hij het Evangelie, nl. het teeken des kruises, als wij Vischer's vermoeden vclgan mogen. ${ }^{13}$ ) Heel de oergeschiedenis is van den val af een wonderlijk heen en weer tusschen wet en Evangelie, liever nog: wij zien hier telkens Evangelie tot wet en wet tot Evangelie worden. Nimmer kan men zeggen: dit blijft wet; op het meest onverwachte oogenblik onthult het zich als Evangelie.

Van de oergeschiedenis wenden wij ons tot het verbond met Abraham. In het middelpunt van de verbondssluiting staat de besnijdenis. In dit sacrament van het Oude Verbond zijn Evangelie en wet onscheidbaar één. De besnijdenis wordt door God gegeven als een teeken van zijn verkiezing en belofte. Niet natuurlijk in den zin, waarin vele nieuwere auteurs dit verstaan, als zou de besnijdenis (evenals de Sabbat, door een analoog misverstand) een teeken zijn, waardoor men $z$ ich van de overige volkeren onderscheidde $\left.{ }^{14}\right)$, maar als een teeken voor Israël zelf, een voortdurende verzekering van het verbond, een dagelijksche troost en een gedurige herinnering aan Gods belofte.

$\left.{ }^{12}\right)$ Zoo staat het letterlijk in den Hebreeuwschen tekst. Alle vertaligen haast wijzigen "met" in „van", ook de Statenvertaling; deze wijziging neemt de pointe van vrome hoogmoed weg.

13) W. Vischer, Das Christuszeugnis des A.T., I. 1935, p. 91-95; vroeger reeds in: Jahwe, der Gott Kains, 1929.

14) Bv. P. Volz, Die biblischen Altertümer, 1914, p. 86. 
De belofte Gods aan Abraham was bovenal, dat hij vader van menigte der volkeren worden zou. Als teeken dezer belofte moet nu echter een verminking van het voortplantingsorgaan plaats vinden. Eenerzijds ontvangt Abraham een klare en blijde belofte, die hem een wondere toekomst verzekert; anderzijds is $z \mathrm{ij}$ onafscheidelijk met bloed en pijn verbonden. Dat wordt nog veel duidelijker, als wij letten op den alouden zin der besnijdenis, die velen volkeren bekend is. De voorhuid staat volgens den regel van pars pro toto voor het mannelijk lid, dit wederom pars pro toto voor den geheelen mensch.'s) De besnijdenis is dus de dood des menschen. De mensch moet sterven; vleesch en bloed beërven het koninkrijk Gods niet. Het Godsvolk is het volk, dat gestorven is. Er geschiedt geen genade dan door den dood heen.

Maar anderzijds: het doode volk is het volk van de opstanding uit de dooden. Abraham heeft zijn zoon bij gelijkenis uit de dooden wedergekregen (Hebr. 11 : 19). Men ziet, hoe wet en Evangelie hier weer één zijn: dat de geheele mensch Gode toebehoort, en dat hij in zijn zonde zich slechts door den dood den Heilige toewijden kan, dat is wet en de vloek der wet; maar dat de mensch, die de belijdenis voltrekken moet, den nieuwen naam reeds ontvangen heeft, den naam Abraham, die aan de menigte van volkeren herinnert, dat is Evangelie. En Abraham wordt tot een groot volk gemaakt niet door eigen kracht of godzaligheid, maar door de genade van den God, die de dooden levend maakt en de dingen, die niet zijn, roept, alsof zij waren (Rom. $4: 17$.)

Wat zal men hier nog van een aparte ethiek spreken? Het eenige "gebod" bij de stichting van het Abrahamietisch verbond is juist het gebod, zich te besnijden, dat wil zeggen, te sterven met daarbij de belofte, dat God levend maakt. Wat is dat anders dan het gebod te gelooven?

Maar is er ook niet dat andere gebod, dat waar Gen. $17: 1$ over spreekt: "Wandel voor mijn aangezicht en wees oprecht?" Dat kan verstaan worden als een aansporing tot een eerlijk burgerlijk leven Maar dat zou een misverstand zijn. "Oprecht" is de vertaling van het Hebreeuwsche tamim, volkomen. Abraham moet geheel en al overgegeven zijn aan den God, die hem geroepen heeft. Hij mag niet anders zijn dan een mensch, die onder Gods oordeel en Gods genadz staat; hij moet geheel sterven, opdat zijn leven geheel en al Gods leven zij. Hij mag niet in de positie zijn van een mensch, die ook nog iets ander heeft; tamim sluit eventueele reserves uit. Dit andere gebod is dus geen ander dan het eerste; Abraham moet en mag enkel gelooven. Dit is het werk Gods, dat hij gelooft.

${ }^{15)}$ F. M. Th. Böhl. Het O.T., p. 50. 
Vandaar immers, dat alle menschelijke pogingen van Abraham, om zich een nakroost te verschaffen, onder Gods bestel mislukken : Lot, Eliëzer (Gen. 15 : 2) en Ismaël. Het uitvoerigst wordt de tragedie met Ismaël beschreven. Die is kennelijk de poging van mensch, om toch ook iets zelf te doen. Vanuit deze gedachte wordt het duidelijk. dat Paulus in Gal. 4 : 21-31 waarachtige exegese heeft bedreven, en dat alle praat over Paulus' allegorese op deze plaats hieruit voortkomt, dat men zelf zoo druk bezig is geweest, een "volksverhaal" te interpreteeren, dat men aan exegese der Heilige Schrift niet meer toe gekomen is.

Wij naderen thans den Sinaĩ en de „wet der tien geboden". Voorop gesteld $z \mathrm{ij}$, dat iedere goede Jood zich zeer en met recht er over ergert, dat wij altijd over "de tien geboden" spreken. De Schrift noemt ze niet .,geboden" maar "woorden". Ongetwijfeld is het Hebreeuwsche dabar meer dan enkel "woord" als aanduiding van een begrip; het is dynamisch, en gesproken door God heeft het tegelijk scheppende en normatieve kracht ${ }^{16}$ ); maar de vertaling ,gebod" brengt ons zeker niet in de rechte sfeer. Een werkelijk goede vertaling is niet te vinden.

Beschouwen wij het eerste "woord" eens nader. Terecht legt Barth er telkens den nadruk op, dat dit eerste ..gebod" alle geboden in zich sluit. De geheelè inleiding op den dekaloog, die in Deut. 6-13 voor ons ligt, is niets anders dan één groote, indrukwekkende prediking over den tekst: Gij zult geen andere goden voor mijn aangezicht hebben. Vandaar de gewichtige plaats, die het sema Jista él in het Joodsche volk bekleedt : Hoor Israël! De HEERE, onze God, is een eenig HEERE! Zoo zult gij den HEERE uw God, liefhebben met uw gansche hart, en met uw gansche ziel, en met al uw vermogen. Het is in zijn kokertje op iederen deurpost bevestigd, en is het laatste woord, dat de stervende Israëliet hoort. ${ }^{27}$ ). Gelijk Duhm ergens zegt, is dit het eenige dogma, dat Israël gekend heeft. Alleen reikt $\mathrm{di}^{+}$ eenige dogma veel verder, dan Duhm heeft willen aanduiden.

Gij zult geen andere goden voor mijn aangezicht hebben-zoo luide het eerste gebod. Maar is dat een gebod? Alleen een gebod? Is het een eisch, die wacht op zijn vervulling door den mensch? Ik zou Barth niet gaarne volgen, als hij met een soort "Entdeckerfreude" betoogt, dat in het Hebreeuwsch een futurum gebruikt wordt: $G_{i j}$ zult. ${ }^{15}$ ) Het is immers een algemeen Semietische eigenaardigheid, dat

10) $\mathrm{Vgl}$. de beschouwingen van Pedersen in Istaêl, its life and culture.

ii) Dit motief is op fraaie wijze gebruikt door Feuchtwangler in het slot van zijn roman Jud Süss.

10) Het ware te wenschen, dat onze dogmatici zich een huis-literator als gedurigen mentor aanschaften, die hen beschermde tegen dergelijke vergissingen, die het wezen der zaak niet raken, maar een schijn van recht geven aan het geschreeuw der Boeotiërs.

166 
men een imperativus niet met behulp van een negative tot een verbod maken kan. De vorm van het vierde gebod ..gedenk den Sabbathdag" toont wel, dat men uit het futurum als zoodanig niet te veel opdiepen moet.

Veel meer zou ik de aandacht willen vestigen op de zoogenaamde inleiding van den dekaloog, het ,Ik ben de HEERE uw God, die $u$ uit Egypteland, uit het diensthuis uitgeleid heb," die in werkelijkheid in het geheel geen inleiding is. Met vergelijking van Assyrisch materiaal, de beginregelen deur koningsinscripties, en opschriften of Syrische vorsten-stèles, is het door $A$. Poebel aannemelijk gemaakt, dat wij het „Ik, de HEERE”, enz., niet als een zelfstandige nominalen zin op te vatten hebben, doch als een bijstelling, staande in een casus pendens bij het ,ik", dat in "voor mijn aangezicht" steekt. ${ }^{19}$ ) Dat leidt tot een verbeterde vertaling, waarin wij het "voor mijn aangezicht" ter wille van het Nederlandsch met ,"naast mij" zullen weergeven : „Naast Mij, de HEERE uw God die u uit Egypteland, uit het diensthuis, uitgeleid heb, zult gij geen andere goden hebben. ${ }^{20}$ )

Wanneer wij zoo den zin weergeven. verstaan wij, dat de dekaloog begint met het Evangelie: er heeft een verlossing plaats gevonden, de kinderen Israëls zijn bevrijde slaven. De wet, die hun gegeven wordt, wil niets anders dan dit eene: dat zij vrij blijven, wat onder de gegeven omstandigheden beteekent, dat zij bij hun Bevrijder blijwen. De vrijheid, waarin zij door de verlossing uit Egypte geplaatst zijn, is geen vrijheid, die in zichzelve of in henzelven zijn grond vindt; het is een geschonken vrijheid, die enkel zijn grond vindt in den Schenker. Willen zij derhalve vrij blijven, dan moeten $z i j$ bij hun Verlosser blijven, en dat kan enkel beteekenen, dat $z i j$ in hun God, en alleen in Hem gelooven, d.w.z. verstaan en aanvaarden, dat hun geheele bestaan als verlosten slechts in Hem en nergens anders gegrondvest kan zijn.

Deze gedachte beheerscht de geheele wetgewing in Israël. De wet is een heining, om andere goden buiten te sluiten en het volk bij zijn Verlosser te houden. Vandaar de negatieve vorm der meerderheid der geboden. Positief van vorm zijn vooral de dusgenaamde ôtôt, de regelingen, die de verhouding tusschen God en Israël tot uitdrukking brengen. De positieve inhoud der geboden is samen vatten in het ééne gebod: Blijft bij uw Bevrijder. Daarom worden de spijzen, die anderen volken heilig waren, den Israëlieten juist onrein; daarom zijn de heilige mysterie-riten, b.v. het koken van het bokje in melk der moeder, en alles wat met doodenriten tezamen hangt, voor Israël een gruwel. Door al deze dingen zou Israël immers verleid kunnen worden, om zijn vertrouwen op menschelijke zekerheden

19) A. Poebel, Das appositionell bestimmte Pronomen der 1 Person singularis in den "westsemitischen Inschriften und in A.T.. Chicaqo, 1932.

20) Den bewerkers van de nieuwe Bijbelvertaling aanbevolen! 
te stellen, in plaats van reddeloos afhankelijk te blijven van zijn God.

De cultus spreekt van dezelfde dingen. Köhler ${ }^{21}$ ) behandelt hem onder de anthropologie, als zelfverlossing des menschen, maar een dergelijke beschouwing is volstrekt onbijbelsch. De geheele cultus zegt immers juist, dat de uitdelging der schuld Gods zaak is. Dat de mensch in den cultus toch de situatie schijnt te scheppen, waarin het goddelijk handelen zich gaat afspelen, doet niets ter zake, daar ieder offer beeld en profetie is van het éene offer op Golgotha, waar God de situatie schiep, Hand. 2 : 23. Blijft bij uw Verlosser: dat is Evangelie en wet tegelijkertijd. Het Evangelie gaat voorop; dat heeft Barth zeer goed gezien; en de wet is tenslotte niet anders dan de roep, bij zijn Verlosser te blijven, m.a.w. te gelooven, zijn verlossing aan te nemen. Het gebod tot geloof brengt tot dit geloof; het is te vergelijken met het lokken van de kuikens door de hen: de geluiden, die de hen maakt, zijn niet enkel een objectieve mededeeling: daar is gevaar en hier ben ik-neen, ze doen wat, ze brengen de kuikens naar de moeder. Maar niet als stok en blok: Jeruzalem, Jeruzalem, hoe menigmaal heb Ik uwe kinderen willen bijeenvergaderen, gelijkerwijs een hen hare kiekens onder de vleugelen vergadert. en gijlieden hebt niet gewild. ${ }^{22}$ )

In de vierde plaats iets over Evangelie en wet bij de profeten. Uit de onderzoekingen der laatste jaren wordt één ding steeds duidelijker, namelijk dat het den profeten niet zoozeer om een zedelijken levenswandel als zoodanig te doen is, doch veeleer om het geloof in den levenden God. Tegen Volz, die onlangs nog eens in het kort de opvatting heeft herhaald ${ }^{23}$ ), welke vrijwel alle profeten-boeken der laatste vijftig jaar beheerscht ${ }^{24}$ ), namelijk dat de profeten in de eerste plaats verkondigers van de zedelijke wereldorde waren, zou ik gaarne de stelling verdedigen, dat het zedelijke bij de profeten eerder een con tingente rol speelt en geen doel in zich zelf is. Dit probleem eischt echter een afzonderlijke studie.

Wel staat het nu echter vast, dat wij niet meer alles, wat op een belofte lijkt, als een latere interpolatie schrappen kunnen; evenmin is het mogelijk, te zeggen, dat de profeten geen interesse voor den cultus gehad hebben. Wanneer Micha b.v. de duizenden lammeren, de tienduizenden van oliebeken afwijst ${ }^{25}$ ), wijst hij niet den waarachtigen cultus af, maar het menschelijk misverstand, dat deze inderdaad,

21) L. Köhler, Theologie des A.T., 1936, p. 169 e.w.

$\left.{ }^{22}\right)$ Mt. 23: 37; Luc. 13: 34; Uit het ", hoe menigmaal" te willen concludeeren. dat ook de Synoptici van meer dan één verblijf te Jeruzalem weten, is een miskenning van het bewustzijn, dat uit het "Ik" spreekt.

$\left.{ }^{23}\right)$ P. Volz, Die radikale Ablehnung der Kultreligion durch die alttestamentliche Propheten, Zeitsch. f. systematische Theologie, 1937, p. 63 e.vv.

${ }^{24}$ ) Cornill. Duhm, Hölscher; ten onzent De Buck en Boschma. Typeerend is. hoe slecht Ezechiël en de na-exilische profeten er af komen; In het boek van Edelkoort over Nahum, Habakuk en Zefanja (1937) liggen de zaken al eenigszins anders. 
zooals Köhler wilde, tot zelfverlossing des menschen maakte, en trachtte, door exorbitante prestaties het heil aan zich te trekken. En wanneer hij vervolgens zijn wet geeft, dan spreekt hij van rechtvaardigheid, liefde en deemoed-juist die dingen, die slechts dáár kunnen zijn, waar geloof is, d.w.z waar de mensch zijn leven aan God toevertrouwt: daar hoeft hij zijn eigen belang niet meer ten koste van dat van anderen te verdedigen (gerechtigheid); daar is liefde jegens God en het maaksel zijner handen; daar is, ongezocht en zonder eenige pretentie, het deemoedig wandelen voor Gods aangezicht.

Enkele jaren geleden schreef ik in een opstel over Christus in het Oude Testament, dat men de geschiedenis van de profetie in Israël misschien het beste kon schrijven, uitgaande van de vraag, hoe groot bij iederen profeet de afstand tusschen oordeel en genade is. Dit program bleek onuitvoerbaar. Wanneer men er aan vasthoudt, vergeet men, dat het feit van de profetie zelf, het feit, dat God iets tot zijn volk te zeggen heeft, altijd oordeel en genade tegelijkertijd is. Over geschiedenis en ontwikkeling der profetie kan men enkel spreken, als men de profétie los maakt van den God, die ze tot zijn volk zendt, gelijk in de meeste studies over de profeten ook inderdaad geschiedt.

$\mathrm{Nu}$ zou men kunnen vragen, hoe de profeten hebben gesproken, waar ze als zielszorgers en raadgevers optreden moesten. Allereerst moet worden opgemerkt, dat het rechte aequivalent voor ,zielzorg" in het Oude Testament niet voorkomt. ${ }^{26}$ ) Waar wij echter meenen de zaak toch hier en daar te vinden, daar is het noodig, nauwkeurig toe te zien.

Kittel heeft Ezechiël, voornamelijk op grond van het derde hoofstuk zijne profetieën, dan eersten zielzorger onder de profeten genoemd. Maar men kan ook bij vroegere profeten iets dergelijks vinden. Zoo b.v. is Jer. 45, waar de profeet zijn secretaris Baruch troosten moet. Deze klaagt namelijk, dat de HEERE droefenis tot zijn smart gedaan heeft; hij is moede van zijn zuchten en vindt geen rust. Baruch zou graag toch zoo iets als resultaten in zijn leven zien. En hoe luidt het antwoord van den profeet? Zoo spreekt de HËERE: Zie, dat Ik gebouwd heb, breek Ik af, en dat Ik geplant heb, ruk Ik uit, zelfs dit gansche land; en zoudt gij u groote dingen zoeken? Zoek ze niet: want zie, Ik breng een kwaad over alle vleesch, spreekt de HEERE; maar ik zal u. uwe ziel tot een buit geven, in alle plaatsen, waar gij zult henentrekken.

Wat is hier zielzorg? Is dit scherpe woord een troost? Jeremia moet Baruch terechtwijzen: bij de groote daden Gods in zijn oordeel over land, volk en tempel is het ongepast, dat een mensch over zijn particuliere belangen praat. En mag het een troost heeten,

${ }^{26)}$ Met Ps. $152: 5 \mathrm{c}$ is dikwijls op vrome wijze gesold. 
dat Baruch zijn leven niet op gewelddadige wijze verliezen zal, waar hij toch juist ${ }^{\circ}$ over de vruchteloosheid van dit leven geklaagd heeft? Doch niettemin wordt hier goddelijke troost gehoord: laat de mensch acht geven op het werk Gods, en daarbij afleeren naar resultaten te vragen; en hij mag weten, dat hij niet van God vergeten is, evenmin als de vijf muschjes, die voor twee penningskens verkocht worden.

Men zou nog bij een vroegeren profeet-zielzorg kunnen zoeken: bij Jesaja, die tot koning Achaz gezonden wordt (Jes. 7). Koning Achaz heeft het ".Gebot der Stunde" verstaan en zorgt voor de watertoevoer in Jeruzalem, eer de vijand er het beleg voor slaat. Jesaja zegt niet: het is goed, dat gij hiermede bezig zijt; hij zegt evenmin: het is verkeerd. Had men de beroemde vraag gesteld: "Maar wat moeten wij doen?" dan zou hij waarschijnlijk geen antwoord gegeven hebben. Hij heeft maar één ding te zeggen: dat Achaz niet bevreesd hoeft te zijn, doch gelooven moet: Indien gijlieden niet gelooft, zekerlijk gij zult niet bevestigd worden. Jesaja's zielzorg is geen oplossing van allehand practische of ethische vraagstukken; ze bepaalt zich tot het eene: gij moogt gelooven; en dat is blijde tijding en wet in één. Blijde tijding, Evangelie: want de profeet geeft te verstaan, dat wij God aan het werk mogen laten. En wet: als Achaz niet ingaat op de boodschap, lokt hij het oordeel uit: Is het ulieden te weinig, dat gij menschen moe maakt, dat gij ook mijn God ${ }^{27}$ ) moe makt? Doch in dit oordeel ligt de belofte weer verscholen, en nog wel die van den Immanuël! Het Evangelie, dat in deze aankondiging besloten ligt, is zoo machtig, dat de geheele historische aanleiding er zijn beteekenis door verliest. Het eenige, wat wij van de geschiedkundige omstandigheden hoeven te onthouden, is dat er aan 's menschen zijde zonde is, gebrek aan geloof. Gods antwoord daarop is niet een psychologische toeleiding tot geloof, maar de verkondiging van zijn werk.

Het wordt wel duidelijk, dat zielzorg bij de profeten niet is, wat wij daar gemeenlijk onder verstaan. Directeurs d'ames zijn zij zeer bepaald niet geweest. Altijd wijzen zij op Gods werken. Het is hun er niet in de eerste plaats om te doen, den mensch tot een bepaalde levenshouding te brengen, doch veeleer, om van Gods werk te getuigen. Dat het geloovig zien naar Gods werk ook zijn persoonlijke en maatschappelijke gevolgen kan hebben, is voor hen van minder belang. Gods eer is hun meer dan de menschenziel of de maatschappelijke orde. Natuurlijk weten ook zij van de zegeningen, die door het geloof mensch en volk kunnen toekomen. Maar zij leggen het daar niet op aan. Elk der profeten heeft verstaan, dat eerst het koningschap Gods en zijne gerechtigheid gezocht moet worden, en dat al die andere dingen ons wel zullen worden toegeworpen.

27) Twee, verzen te voren, eer Achaz ontwijkend geantwoord had. was het nog: „uw God". 
Van hieruit zullen wij Ezechiël beter kunnen verstaan. Deze zielzorger onder de profeten heeft zich naar het schijnt in het geheel niet over de zielen als zoodanig bekommerd, maar getuigt elk oogenblik van de eere Gods. Juist van hem is het merkwaardige woord: Ik doe het niet om Uwentwil, gij huis Isräls, maar om mijn heiligen naam, dien gijlieden ontheiligd hebt." ) Dat hij daarom, juist daarom, een beter zielzorger geweest is dan alle directeuts d'ames bij elkander, dat behoort wederom tot de dingen, die toegeworpen zullen worden.

Het is dus niet mogelijk, de zedelijke eischen van de profeten afgescheiden van hun aankondiging vạn Gods werk te houden. Ook voor hen is de wet geen aparte grootheid. In wezen gaat het bij de profeten, gelijk als in heel het Oude Testament, enkel en alleen om Gods werk, dat van ons niets anders vraagt dan geloof alleen.

A. VAN SELMS. 